\title{
Leaf Gas Exchange and Chlorophyll $a$ Fluorescence in Wheat Plants Supplied with Silicon and Infected with Pyricularia oryzae
}

\author{
Carlos Eduardo Aucique Perez, Fabrício Ávila Rodrigues, Wiler Ribas Moreira, and Fábio Murilo DaMatta
}

First and fourth authors: Department of Biology, and second and third authors: Department of Plant Pathology, Laboratory of Host-Parasite Interaction, Viçosa Federal University, Viçosa, Minas Gerais State, 36.570-000, Brazil.

Accepted for publication 9 September 2013.

\section{ABSTRACT}

Aucique Perez, C. E., Rodrigues, F. A., Moreira, W. R., and DaMatta, F. M. 2014. Leaf gas exchange and chlorophyll $a$ fluorescence in wheat plants supplied with silicon and infected with Pyricularia oryzae. Phytopathology 104:143-149.

This study investigated the effect of silicon $(\mathrm{Si})$ on the photosynthetic gas exchange parameters (net $\mathrm{CO}_{2}$ assimilation rate $[A]$, stomatal conductance to water vapor $\left[g_{s}\right]$, internal $\mathrm{CO}_{2}$ concentration $\left[C_{i}\right]$, and transpiration rate $[E]$ ) and chlorophyll fluorescence $a$ parameters (maximum quantum quenching $\left[F_{v} / F_{m}\right.$ and $\left.F_{v}{ }^{\prime} / F_{m}{ }^{\prime}\right]$, photochemical $\left[q_{P}\right]$ and nonphotochemical [NPQ] quenching coefficients, and electron transport rate [ETR]) in wheat plants grown in a nutrient solution containing $0 \mathrm{mM}$ $(-\mathrm{Si})$ or $2 \mathrm{mM}(+\mathrm{Si}) \mathrm{Si}$ and noninoculated or inoculated with Pyricularia oryzae. Blast severity decreased due to higher foliar Si concentration. For the inoculated + Si plants, $A, g_{s}$, and $E$ were significantly higher in contrast to the inoculated $-\mathrm{Si}$ plants. For the inoculated $+\mathrm{Si}$ plants, significant differences of $F_{v} / F_{m}$ between the $-\mathrm{Si}$ and $+\mathrm{Si}$ plants occurred at 48, 96, and $120 \mathrm{~h}$ after inoculation (hai) and at 72,96 , and 120 hai for $F_{v}{ }^{\prime} / F_{m}{ }^{\prime}$. The $F_{v} / F_{m}$ and $F_{v}{ }^{\prime} / F_{m}{ }^{\prime}$, in addition to total chlorophyll concentration $(a+b)$ and the chlorophyll $a / b$ ratio, significantly decreased in the $-\mathrm{Si}$ plants compared with the $+\mathrm{Si}$ plants. Significant differences between the $-\mathrm{Si}$ and $+\mathrm{Si}$ inoculated plants occurred for $q_{P}, \mathrm{NPQ}$, and ETR. The supply of Si contributed to decrease blast severity in addition to improving gas exchange performance and causing less dysfunction at the photochemical level.

Additional keywords: photosynthesis, Triticum aestivum.
In Brazil, epidemics of blast, caused by the fungus Pyricularia oryzae Cavara (teleomorph Magnaporthe grisea (T. T. Hebert) M. E. Barr), have limited wheat (Triticum aestivum L.) production (17). On spikes and spikelets, where the blast symptoms are more pronounced, the occurrence of gray-brown lesions contributes to a reduced yield due to the reduced translocation of nutrients to the grains (16). Gray-green and water-soaked lesions with dark green borders are the symptoms occurring on the leaves (17). Seedling blight, spike tip death, and bright black spots on the rachis are other common symptoms caused by $P$. oryzae (16). Blast has been controlled using seed treatment with fungicides, the application of systemic fungicides at different plant growth stages, and the use of cultivars with high level of resistance $(8,9)$.

Several abiotic and biotic stresses that are imposed on plants may cause changes in their growth and development (4). Pathogens affect plant physiology by negatively impacting the leaf gas exchange due to losses in healthy leaf area or by lowering the efficiency of the photosynthetic process (36). For different hostpathogen interactions, the reduction in pigment concentration, structural damage to the chloroplasts, impairments in energy dissipation via chlorophyll (Chl) $a$ fluorescence, and increases in leaf temperature are the most notable negative effects that result from pathogen infection $(30,31,39)$. In addition to pathogen infection damaging a host's photosynthesis capability, several studies have demonstrated that pathogens also cause leaf damage at the cuticular and stomatal levels, which can lead to changes in transpiration, plant water balance, and, ultimately, plant canopy temperature (2).

Corresponding author: F. A. Rodrigues; E-mail address: fabricio@ufv.br

http://dx.doi.org/10.1094/PHYTO-06-13-0163-R

(c) 2014 The American Phytopathological Society
In healthy plants, silicon ( $\mathrm{Si}$ ) is believed to have a negligible effect on metabolism, which suggests its nonessential role (15). However, recent studies have revealed a role for $\mathrm{Si}$ nutrition in promoting agronomic yields of unstressed crops such as rice $(14,37)$. The most positive and consistent effects of Si nutrition have been found in the alleviation of both abiotic and biotic stresses in a wide variety of plant species $(15,18)$. In particular, Si is distinguished by its potential to decrease the intensity of important diseases in several crops, especially in grasses and some dicots such as bean, soybean, and cucumber (12). The biochemical and physiological mechanisms that are potentiated by $\mathrm{Si}$ include the high concentration of phenolics, lignin, and phytoalexins; an increase in the activities of defense enzymes such as chitinases and $\beta$-1,3-glucanases; and the rapid transcription of genes associated with plant resistance (5,23,33-35). Furthermore, increased resistance of plants supplied with $\mathrm{Si}$ against pathogens has also been associated with a physical barrier that prevents or slows fungal penetration; such a barrier can result from an increase in the density of the long and short silicate cells in the leaf epidermis or from a thick silica layer below the cuticle, as noted in the case of the rice- $P$. oryzae pathosystem (19).

Regarding the wheat $-P$. oryzae interaction, Xavier Filha et al. (38) demonstrated that supplying $\mathrm{Si}$ to the wheat plants resulted in reduced levels of blast symptoms. More recently, Debona et al. (13) noted that the net $\mathrm{CO}_{2}$ assimilation rate $(A)$, stomatal conductance to water vapor $\left(g_{s}\right)$, and transpiration rate $(E)$ were dramatically reduced in two wheat cultivars with contrasting levels of resistance to blast, although such reductions occurred to a greater extent for the susceptible cultivar. The decreases in $A$ were largely attributed to the biochemical limitations of $\mathrm{CO}_{2}$ fixation. The authors also suggested that $A$ was impaired in asymptomatic leaf tissues, which suggested that blast severity was not a good indicator for predicting $P$. oryzae-induced reductions in $A$. Given the facts described above and considering that $\mathrm{Si}$ 
could help to maintain the photosynthetic rates in plants infected with foliar pathogens $(10,31)$, it is hypothesized that the supply of Si could mitigate the deleterious effects of the $P$. oryzae infection on wheat plants, which could be translated into maintenance of the functionality of the photosynthetic apparatus. To test this hypothesis, the combined gas exchange and Chl $a$ fluorescence measurements, along with an analysis of the Chl pools, were used to examine the photosynthetic performance of wheat plants supplied with Si during the infection process of P. oryzae.

\section{MATERIALS AND METHODS}

Nutrient solution preparation. The nutrient solution used in this study was prepared as described by Clark (7) and included the following nutrients: $1.04 \mathrm{M} \mathrm{Ca}\left(\mathrm{NO}_{3}\right)_{2} \cdot 4 \mathrm{H}_{2} \mathrm{O}, 1 \mathrm{M} \mathrm{NH}_{4} \mathrm{NO}_{3}$, $0.8 \mathrm{M} \mathrm{KNO}_{3}, 0.6 \mathrm{M} \mathrm{MgSO}_{4} \cdot 7 \mathrm{H}_{2} \mathrm{O}, 6.9 \mathrm{mM} \mathrm{KH}_{2} \mathrm{PO}_{4}, 9.3 \mathrm{mM}$ $\mathrm{KCl}, 2 \mathrm{mM} \mathrm{H}_{3} \mathrm{BO}_{3}, 2 \mathrm{mM} \mathrm{ZnSO} 4 \cdot 7 \mathrm{H}_{2} \mathrm{O}, 7 \mathrm{mM} \mathrm{MnCl} \mathrm{Mn}_{2} \cdot 4 \mathrm{H}_{2} \mathrm{O}$, $0.5 \mathrm{mM} \mathrm{CuSO}_{4} \cdot 5 \mathrm{H}_{2} \mathrm{O}, 0.6 \mathrm{mM} \mathrm{ZnSO} \mathrm{Zn}_{4} \cdot 7 \mathrm{H}_{2} \mathrm{O}, 90 \mathrm{mM} \mathrm{FeSO}_{4}$ $7 \mathrm{H}_{2} \mathrm{O}$, and $90 \mathrm{mM}$ disodium EDTA. Si was supplied as monosilicic acid and was obtained by passing potassium silicate (PQ Corporation, São Paulo, Brazil) through a column with a cationexchange resin (Amberlite IR-120B, $\mathrm{H}^{+}$form; Sigma-Aldrich, São Paulo, Brazil) (26). Si was applied at $2 \mathrm{mM}$ while nonamended $\mathrm{Si}(0 \mathrm{mM})$ served as the control. The addition of monosilicic acid to the nutrient solution did not alter the $\mathrm{pH}$.

Plant growth. Wheat seed (T. aestivum) from 'BRS-Guamirim', a commercially grown Brazilian cultivar susceptible to blast (9), were surface sterilized in $10 \%$ ( vol/vol) $\mathrm{NaOCl}$ for $2 \mathrm{~min}$, rinsed in sterilized water for $3 \mathrm{~min}$, and germinated on a sand substrate at $25^{\circ} \mathrm{C}$ for 8 days. The germination seedlings were transferred to plastic pots (20 cm in diameter) (Ecovaso, Jaguariúna, São Paulo, Brazil) with half-strength nutritive solution without Si for 7 days. Then, plants were transferred to plastic pots (five plants per plastic pot with five replications) containing 5 liters of nutrient solution prepared with or without $\mathrm{Si}$. The nutrient solution was changed every 4 days and its $\mathrm{pH}$ was measured daily. The $\mathrm{pH}$ was maintained at approximately 5.8 by adding $\mathrm{NaOH}$ or $\mathrm{HCl}(1 \mathrm{M})$ when necessary. The plants were grown in a greenhouse with relative humidity of $70 \pm 5 \%$, temperature of $25 \pm 3{ }^{\circ} \mathrm{C}$, and natural photosynthetically active radiation (PAR) of $900 \pm 15 \mu \mathrm{mol}$ photons $\mathrm{m}^{-2} \mathrm{~s}^{-1}$, which was measured at midday.

Inoculum production and inoculation procedure. A pathogenic isolate of $P$. oryzae (UFV/DFP Po-01) obtained from the wheat spikes of 'BR-18' wheat was used to inoculate the plants (13). Disks of filter paper containing fungal mycelia were transferred to petri dishes containing oat-agar medium. After growing the disks containing mycelia, the media with the fungus were transferred to new petri dishes containing the same medium. The dishes were incubated in a growth chamber at $25^{\circ} \mathrm{C}$ with a $24-\mathrm{h}$ photoperiod for 10 days. After this period, conidia were carefully removed from the petri dishes with a soft bristle brush using water containing gelatin $(1 \% \mathrm{wt} / \mathrm{vol})$. The conidial suspension was calibrated with a hemacytometer to obtain a concentration of $1 \times 10^{5}$ conidia $\mathrm{ml}^{-1}$. The conidial suspension was sprayed with an atomizer (Paasche Airbrush Co., Chicago) on the adaxial surface of the leaves of wheat plants at stage 39 (22). After inoculation, the plants were kept in the dark in a mist chamber at $25^{\circ} \mathrm{C}$ for $24 \mathrm{~h}$. The plants were then transferred to a greenhouse with a relative humidity of $80 \pm 5 \%$ with a temperature of $25 \pm 3^{\circ} \mathrm{C}$.

Blast severity assessment. The fourth and fifth leaves (from the top) of each plant (per replication for each treatment) were marked and used to evaluate the blast severity at 48, 72, 96, and $120 \mathrm{~h}$ after inoculation (hai) using the scale proposed by Rios et al. (32). The area under blast progress curve (AUBPC) for each leaf was computed using the trapezoidal integration of the blast progress curve over time using the formula proposed by Campbell and Madden (6).
Photosynthetic measurements. The leaf gas exchange parameters were simultaneously determined via conducting the measurements of Chl $a$ fluorescence by using a portable open-flow gas exchange system (LI-6400XT; Li-Cor Inc., Lincoln, NE) equipped with an integrated fluorescence chamber head (LI-640040; Li-Cor Inc.). The net $\mathrm{CO}_{2}$ assimilation rate $(A)$, stomatal conductance to water vapor $\left(g_{s}\right)$, internal $\mathrm{CO}_{2}$ concentration $\left(C_{i}\right)$, and transpiration rate $(E)$ were measured from the attached leaves (fourth leaf from the top of the plant per replication for each treatment) at 48, 72, 96, and 120 hai from 0900 to $1100 \mathrm{~h}$ (solar time), which is when $A$ was at its maximum under artificial PAR (i.e., $1,000 \mu \mathrm{mol}$ photons $\mathrm{m}^{-2} \mathrm{~s}^{-1}$ at the leaf level and $400 \mu \mathrm{mol}$ atmospheric $\mathrm{CO}_{2} \mathrm{~mol}^{-1}$ ). All of the measurements were performed at $25^{\circ} \mathrm{C}$ and the vapor pressure deficit was maintained at approximately $1.0 \mathrm{kPa}$, while the amount of blue light was set to $10 \%$ of the photosynthetic photon flux density (PPFD) to optimize the stomatal aperture.

Previously dark-adapted (30 $\mathrm{min}$ ) leaf tissues were illuminated with weak, modulated measuring beams $\left(0.03 \mu \mathrm{mol} \mathrm{m} \mathrm{m}^{-2} \mathrm{~s}^{-1}\right)$ to obtain the initial fluorescence $\left(F_{0}\right)$. Saturating white light pulses of $8,000 \mu \mathrm{mol}$ photons $\mathrm{m}^{-2} \mathrm{~s}^{-1}$ were applied for $0.8 \mathrm{~s}$ to ensure maximum fluorescence emissions $\left(F_{m}\right)$, from which the variableto-maximum $\mathrm{Chl}$ fluorescence ratio, $\left.F_{v} / F_{m}=\left[\left(F_{m}-F_{0}\right) / F_{m}\right)\right]$, was calculated. In light-adapted leaves, the steady-state fluorescence yield $\left(F_{s}\right)$ was measured following a saturating white light pulse $\left(8,000 \mu \mathrm{mol} \mathrm{m} \mathrm{m}^{-2} \mathrm{~s}^{-1}, 0.8 \mathrm{~s}\right)$ that was applied to achieve the lightadapted maximum fluorescence $\left(F_{m}{ }^{\prime}\right)$. The actinic light was then turned off and far-red illumination was applied $\left(2 \mu \mathrm{mol} \mathrm{m} \mathrm{m}^{-2} \mathrm{~s}^{-1}\right)$ to measure the light-adapted initial fluorescence $\left(F_{0}{ }^{\prime}\right)$. Using these parameters, the capture efficiency of the excitation energy by the open PSII reaction centers $\left(F_{v}{ }^{\prime} / F_{m}{ }^{\prime}\right)$ was estimated as $F_{v}{ }^{\prime} / F_{m}{ }^{\prime}=$ $\left(F_{m}{ }^{\prime}-F_{0}{ }^{\prime}\right) / F_{m}{ }^{\prime}$. The coefficient for photochemical quenching $\left(q_{P}\right)$ was calculated as $q_{P}=\left(F_{m}{ }^{\prime}-F_{s}\right) /\left(F_{m}{ }^{\prime}-F_{0}{ }^{\prime}\right)$, while that for nonphotochemical quenching (NPQ) was calculated as NPQ = $\left(F_{m} / F_{m}{ }^{\prime}\right)-1$. The actual quantum yield of PSII electron transport $\left(\Phi_{\text {PSII }}\right)$ was computed as $\Phi_{\text {PSII }}=\left(F_{m}{ }^{\prime}-F_{s}\right) / F_{m}{ }^{\prime}$, from which the electron transport rate (ETR) was calculated as ETR $=\Phi_{\text {PSII }} \times$ PPFD $\times f \times \alpha$, where $f$ is a factor that accounts for the partitioning of energy between PSII and PSI and is assumed to be 0.5 , which indicates that the excitation energy is distributed equally between the two photosystems; and $\alpha$ is the leaf absorbance by the photosynthetic tissues and is assumed to be 0.84 (28).

Determination of pigment concentrations. The leaf discs $(1.0 \mathrm{~cm}$ in diameter) obtained from the fourth and fifth leaves (from the top) were collected after the last blast severity and photosynthetic measurements (120 hai). The leaf discs were quickly frozen in liquid nitrogen and then stored at $-80^{\circ} \mathrm{C}$ until needed. Chl $a$ and $b$ were separated on an end-capped, $\mathrm{C}_{18}$, Spherisorb ODS-2 reversed-phase column (particle size $5 \mu \mathrm{m}$, 250 by $4.6 \mathrm{~mm}$ ) and quantified using high-performance liquid chromatography (Dionex Ultimate 3000; Thermo Fisher Scientific, Vantaa, Finland), as described previously (27).

Leaf area and leaf dry mass determinations. The five plants were randomly collected from the replications of each treatment after sampling for pigment concentrations to determinate the leaf area (LA) (in square centimeters) of each plant using an LA meter (model LI-COR 3100; Li-Cor Inc.). The leaf dry mass (LDM) was obtained by placing the samples in an oven with forced air circulation at $70^{\circ} \mathrm{C}$ until a constant weight was obtained.

Determination of foliar Si concentration. After the end of the experiment that was performed to evaluate the blast severity, the leaves were collected from the plants of each replication of each treatment, washed in deionized water, dried for $72 \mathrm{~h}$ at $65^{\circ} \mathrm{C}$, and ground to pass through a 40-mesh screen with a Thomas Wiley mill (Thomas Scientific, Swedesboro, NJ). The foliar Si concentration was determined by colorimetric analysis of $0.1 \mathrm{~g}$ of dried and alkali-digested tissue (20) and was expressed in decagram (dag) per kilogram. 
Experimental design and data analysis. A two-by-two factorial experiment, consisting of two $\mathrm{Si}$ concentrations ( 0 and $2 \mathrm{mM}$; hereafter referred to as the $-\mathrm{Si}$ and $+\mathrm{Si}$ plants, respectively) and noninoculated or inoculated plants, was arranged in a completely randomized design with five replications. The experiment was repeated once. Each experimental unit corresponded to a plastic pot containing five plants. In total, 100 plants were used in each experiment ( 25 plants per each treatment at each evaluation time). The data for all of the variables were subjected to an analysis of variance (ANOVA) and the means from the treatments were compared by $F$ test $(P \leq 0.05)$ using the SAS software (SAS Institute Inc., Cary, NC). For the leaf Si concentration, LA, LDM, and pigment, ANOVA was used and considered to be a two-bytwo factorial experiment consisting of two $\mathrm{Si}$ concentrations and noninoculated or inoculated plants. For the photosynthetic measurements, ANOVA was used and considered to be a two-by-two-byfour factorial experiment consisting of two $\mathrm{Si}$ concentrations, noninoculated or inoculated plants, and four evaluations. The Pearson correlation was used to determine the relationships among the gas exchange parameters, foliar Si concentration, and blast severity for the $-\mathrm{Si}$ and $+\mathrm{Si}$ treatments separately.

\section{RESULTS}

Foliar Si concentration. Only the factor Si concentrations was significant $(P \leq 0.05)$ (Table 1$)$. The leaf $\mathrm{Si}$ concentration was significantly higher in the $+\mathrm{Si}$ plants $\left(1.40 \mathrm{dag}_{\mathrm{kg}}^{-1}\right.$ ) compared

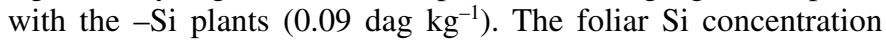
showed a similar trend across treatments based on a preliminary experiment (data not shown).

Blast severity and AUBPC. The factor $\mathrm{Si}$ concentrations was significant $(P \leq 0.05)$ for both blast severity and the AUBPC. The blast severity on the leaves of the $+\mathrm{Si}$ plants was significantly lower at 96 and 120 hai compared with the $-\mathrm{Si}$ plants (Fig. 1A). For the + Si plants, the AUBPC was significantly reduced by $78 \%$ compared with the - Si plants (Fig. 1B). The blast severity showed a similar trend across treatments based on a preliminary experiment (data not shown).

Photosynthetic parameters. At least one of the factors $\mathrm{Si}$ concentrations, plant inoculation (PI), or sampling time (ST) as well as some interactions between these factors were significant for $A, g_{s}, C_{i}$, and $E$ (Table 1). For the noninoculated plants, significant differences between the $-\mathrm{Si}$ and $+\mathrm{Si}$ plants for $A$ occurred only at 48 hai (Fig. 2A) and at 72, 96, and 120 hai for the inoculated plants (Fig. 2B). For the noninoculated plants, $A$ was significantly reduced by $7 \%$ for the $+\mathrm{Si}$ plants compared with the $-\mathrm{Si}$ plants at 48 hai. For the inoculated $+\mathrm{Si}$ plants, $A$ was significantly higher at 72 (14\%), 96 (12\%), and 120 (58\%) hai than in their inoculated -Si counterparts. The $g_{s}$ and $E$ were significantly higher by 60 and $42 \%$, respectively, at 120 hai (Fig. $2 \mathrm{D}$ to $\mathrm{H}$ ) for the inoculated $+\mathrm{Si}$ plants compared with inoculated - Si plants. Significant differences between the noninoculated and

TABLE 1. Analysis of variance of the effects of silicon ( $\mathrm{Si}$ ) concentrations, plant inoculation (PI), sampling time (ST), and their interactions for Si concentration in leaf tissue (leaf $\mathrm{Si}$ ), blast severity (blast), area under blast progress curve (AUBPC), leaf area (LA), leaf dry mass (LDM), photosynthetic gas exchange parameters (net $\mathrm{CO}_{2}$ assimilation rate $[A]$, stomatal conductance to water vapor $\left[g_{s}\right]$, internal $\mathrm{CO}_{2}$ concentration $\left[C_{i}\right]$, and transpiration rate $[E]$ ), chlorophyll fluorescence parameters (maximum quantum quenching $\left[F_{v} / F_{m}\right.$ and $\left.F_{v}{ }^{\prime} / F_{m}{ }^{\prime}\right]$, photochemical $\left[q_{P}\right]$, and nonphotochemical [NPQ] quenching coefficients and electron transport rate [ETR]), and concentration of total chlorophyll (Chl) and the $\mathrm{Chl} a / b$ ratio

\begin{tabular}{|c|c|c|c|c|c|c|c|}
\hline \multirow[b]{2}{*}{ Variables } & \multicolumn{7}{|c|}{$F$ based $P$ values } \\
\hline & $\mathrm{Si}$ & PI & ST & $\mathrm{Si} \times \mathrm{PI}$ & $\mathrm{Si} \times \mathrm{ST}$ & $\mathrm{PI} \times \mathrm{ST}$ & $\mathrm{Si} \times \mathrm{PI} \times \mathrm{ST}$ \\
\hline Leaf $\mathrm{Si}$ & $<0.001$ & 0.086 & & 0.535 & & $\ldots$ & $\ldots$ \\
\hline LA & $<0.001$ & 0.008 & $\ldots$ & 0.697 & $\ldots$ & $\ldots$ & $\ldots$ \\
\hline LDM & $<0.001$ & 0.015 & $\ldots$ & 0.910 & $\ldots$ & $\ldots$ & $\ldots$ \\
\hline$A$ & $<0.001$ & $<0.001$ & $<0.001$ & 0.167 & 0.003 & $<0.001$ & $<0.001$ \\
\hline$E$ & 0.013 & $<0.001$ & $<0.001$ & $<0.001$ & 0.641 & 0.074 & 0.175 \\
\hline$F_{v} / F_{m}$ & $<0.001$ & $<0.001$ & $<0.001$ & 0.160 & 0.049 & 0.001 & $<0.001$ \\
\hline$F_{v}^{\prime} / F_{m}^{\prime}{ }^{\prime}$ & 0.018 & $<0.001$ & 0.001 & 0.463 & 0.540 & $<0.001$ & 0.025 \\
\hline$q_{P}$ & 0.067 & 0.001 & 0.082 & 0.022 & 0.609 & 0.001 & 0.110 \\
\hline NPQ & 0.487 & 0.002 & $<0.001$ & 0.157 & 0.016 & 0.024 & 0.057 \\
\hline ETR & 0.017 & $<0.001$ & $<0.001$ & 0.005 & 0.529 & $<0.001$ & 0.025 \\
\hline Total Chl & 0.023 & $<0.001$ & $\ldots$ & 0.007 & $\ldots$ & $\ldots$ & $\ldots$ \\
\hline
\end{tabular}
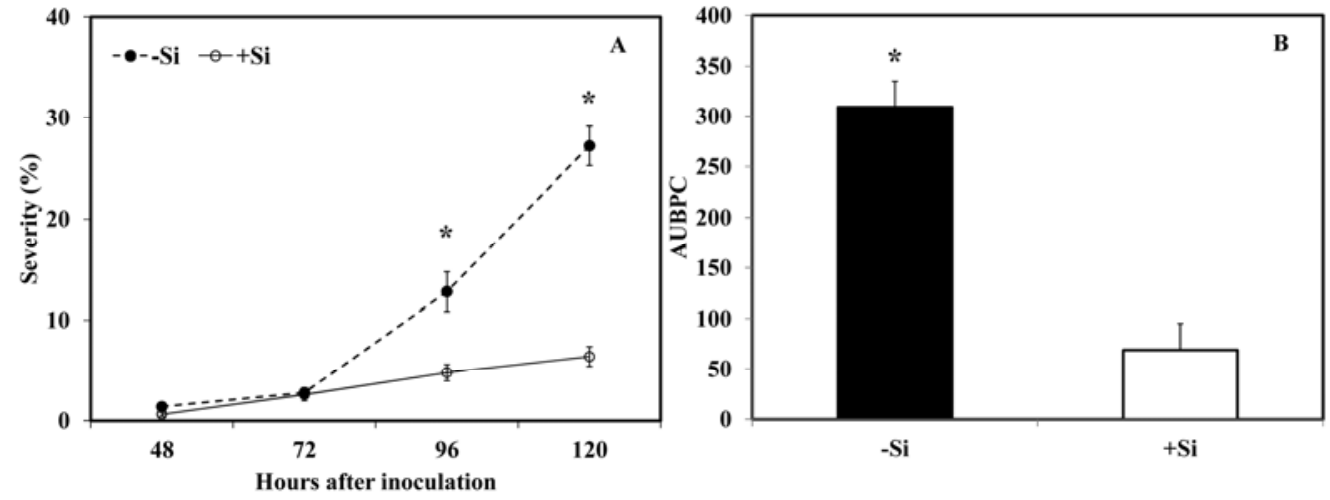

Fig. 1. A, Blast progress curves and $\mathbf{B}$, area under blast progress curve (AUBPC) for wheat plants grown in a hydroponic culture containing $0 \mathrm{mM}$ (-Si) or $2 \mathrm{mM}$ $(+\mathrm{Si})$ silicon $(\mathrm{Si})$. For blast progress, the means for the $-\mathrm{Si}$ and $+\mathrm{Si}$ treatments followed by an asterisk $(*)$ for each evaluation time were significantly different according to Student's $t$ test $(P \leq 0.05)$. Bars represent the standard error of the mean; $n=5$. 
inoculated plants occurred 48 to 120 hai for $A, g_{s}$, and $E$ (Fig. 2A to $\mathrm{B}, \mathrm{C}$ to $\mathrm{D}$, and $\mathrm{G}$ to $\mathrm{H}$ ) and 48 to 96 hai for $C_{i}$ (Fig. $2 \mathrm{E}$ and $\mathrm{F}$ ).

At least one of the factors $\mathrm{Si}, \mathrm{PI}$, or ST as well as some interactions between these factors were significant for $F_{v} / F_{m}, F_{v}{ }^{\prime} / F_{m}{ }^{\prime}$, $q_{P}$, NPQ, and ETR (Table 1). For the inoculated $+\mathrm{Si}$ plants, significant differences for $F_{v} / F_{m}$ between the $-\mathrm{Si}$ and $+\mathrm{Si}$ plants occurred at 48, 96, and 120 hai (Fig. 3B) and at 72, 96, and 120 hai for $F_{v}{ }^{\prime} / F_{m}{ }^{\prime}$ (Fig. 3D). The values of $F_{v} / F_{m}$ significantly decreased by 1,3 , and $5 \%$ at 48,96 , and 120 hai, respectively, in the $-\mathrm{Si}$ plants compared with the $+\mathrm{Si}$ plants (Fig. 3B). Significant decreases of 10,11 , and $22 \%$ occurred at 72, 96, and 120 hai, respectively, for $F_{v}{ }^{\prime} / F_{m}{ }^{\prime}$ in the $-\mathrm{Si}$ plants compared with the $+\mathrm{Si}$ plants (Fig. 3D). Significant differences between the noninoculated and inoculated plants occurred 48-120 hai for $F_{v} / F_{m}$ and $F_{v}{ }^{\prime} / F_{m}{ }^{\prime}$ (Fig. $3 \mathrm{~A}$ to D). For the noninoculated plants, significant differences between the $\mathrm{Si}$ and $+\mathrm{Si}$ plants occurred at 96 hai for $q_{P}$ (Fig. 3E) and at 48 hai for ETR (Fig. 3I). For the inoculated plants, significant differences between the $-\mathrm{Si}$ and $+\mathrm{Si}$ plants occurred at 96 hai for both $q_{P}$ (Fig. 3F) and NPQ (Fig. 3H) and at 72 and 120 hai for ETR (Fig. 3J). Significant differences between the noninoculated and inoculated plants occurred at 120 hai for $q_{P}$ (Fig. 3E and F) and at 96 and 120 hai for ETR (Fig. 3I and $\mathrm{J}$ ). A preliminary experiment to determine the photosynthetic parameters was performed and showed a similar trend for the treatments discussed above (data not shown).

Leaf pigments. At least one of the factors Si or PI as well as their interactions were significant for the total Chl $(a+b)$ concentration and the $\mathrm{Chl} a / b$ ratio (Table 1). Both the total Chl concentration and the Chl $a / b$ ratio significantly decreased for inoculated plants in comparison with the noninoculated ones
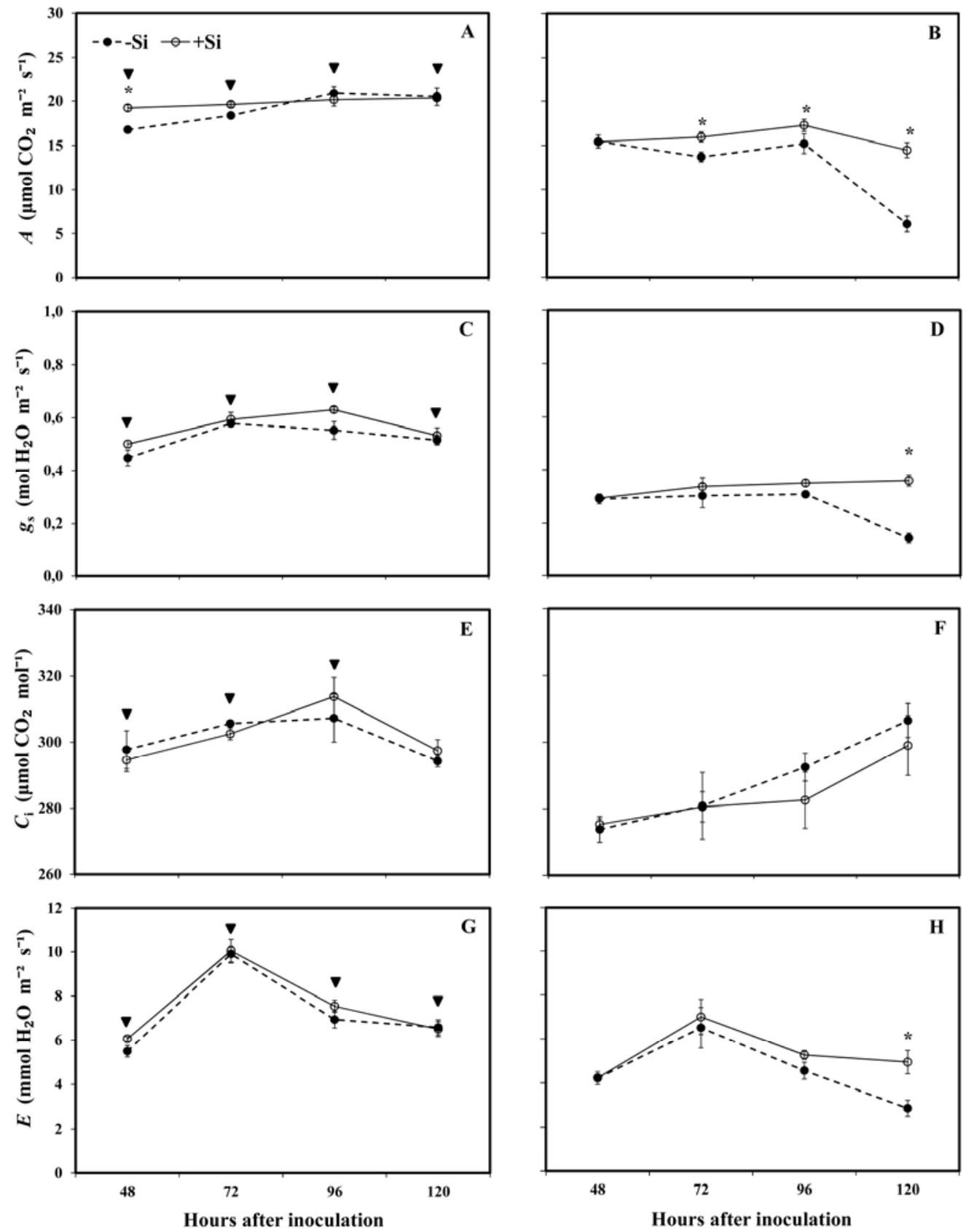

Fig. 2. A and $\mathbf{B}$, Net $\mathrm{CO}_{2}$ assimilation rate $(A) ; \mathbf{C}$ and $\mathbf{D}$, stomatal conductance to water vapor $\left(g_{s}\right) ; \mathbf{E}$ and $\mathbf{F}$, internal $\mathrm{CO}_{2}$ concentration $\left(C_{i}\right)$; and $\mathbf{G}$ and $\mathbf{H}$, transpiration rate $(E)$ for the leaves of wheat plants grown in a hydroponic culture containing $0 \mathrm{mM}(-\mathrm{Si})$ or $2 \mathrm{mM}(+\mathrm{Si})$ silicon $(\mathrm{Si})$ and noninoculated $(\mathrm{NI})(\mathrm{A}, \mathrm{C}$, E, and G) or inoculated (I) (B, D, F, and H) with Pyricularia oryzae. Means for the NI and I treatments followed by an inverted triangle and for the $-\mathrm{Si}$ and $+\mathrm{Si}$ treatments followed by an asterisk (*) for each evaluation time were significantly different according to Student's $t$ test $(P \leq 0.05)$. Bars represent the standard error of the mean; $n=5$. 
regardless of Si supply; notably, such decreases were greater in the $-\mathrm{Si}$ inoculated plants than in the $+\mathrm{Si}$ inoculated plants (Table 2).

Pearson correlation. There was a positive correlation of $A$ with $g_{s}$ and $E$ but $A$ was negatively correlated with $C_{i}$ and the blast severity for both $-\mathrm{Si}$ and $+\mathrm{Si}$ plants (Table 3 ). The $g_{s}$ was negatively correlated with blast severity but positively correlated with $E$ for both $-\mathrm{Si}$ and $+\mathrm{Si}$ plants (Table 3 ). There was a positive correlation between $C_{i}$ and the blast severity for both $-\mathrm{Si}$ and $+\mathrm{Si}$ plants. Significant negative correlation occurred between $E$ and
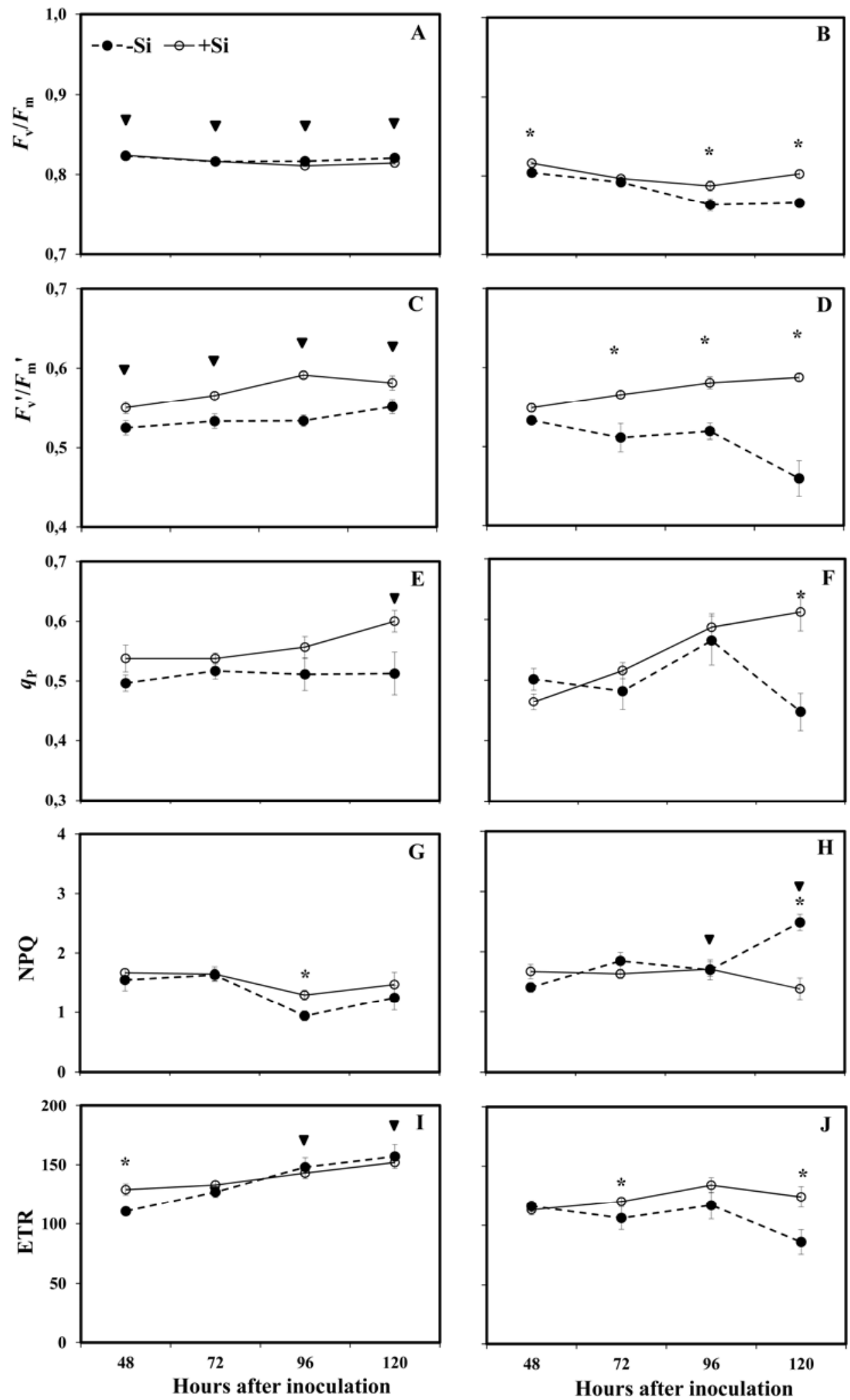

Fig. 3. A and B, Maximum PSII quantum efficiency $\left(F_{v} / F_{m}\right) ; \mathbf{C}$ and $\mathbf{D}$, capture efficiency of excitation energy by the open PSII reaction centers $\left(F_{v}{ }^{\prime} / F_{m}{ }^{\prime}\right)$; and $\mathbf{E}$ to J, photochemical $\left(q_{P}\right)$, and nonphotochemical (NPQ) quenching coefficients and electron transport rate (ETR) for wheat plants grown in a hydroponic culture containing $0 \mathrm{mM}(-\mathrm{Si})$ or $2 \mathrm{mM}(+\mathrm{Si})$ silicon $(\mathrm{Si})$ and noninoculated $(\mathrm{NI})(\mathrm{A}, \mathrm{C}, \mathrm{E}, \mathrm{G}$, and I) or inoculated (I) (B, D, F, H, and I) with Pyricularia oryzae. Means for the NI and I treatments followed by an inverted triangle and for the $-\mathrm{Si}$ and $+\mathrm{Si}$ treatments followed by an asterisk $(*)$ for each evaluation time are significantly different according to Student's $t$ test $(P \leq 0.05)$. Bars represent the standard error of the mean; $n=5$. 
the blast severity for the $-\mathrm{Si}$ plants whereas, for the $+\mathrm{Si}$ plants, this correlation was significantly positive (Table 3 ).

Variables LA and LDM. Only the Si and PI factors were significant for LA and LDM (Table 1). LA and LDM significantly increased by 27.6 and $21.7 \%$, respectively, in the $+\mathrm{Si}$ plants compared with the $-\mathrm{Si}$ plants, whereas they were significantly reduced by 23 and 19\%, respectively, for the inoculated plants compared with the noninoculated plants (Table 4).

\section{DISCUSSION}

In support of previous findings that $\mathrm{Si}$ can improve the resistance of several monocots against foliar pathogens (12), including the wheat-P. oryzae pathosystem (38), the present study is the first to describe the physiological features that are associated with the increase in resistance of wheat plants supplied with $\mathrm{Si}$ to $P$. oryzae infection. Notably, regardless of the Si supply, $P$. oryzae exerted its deleterious effect on the physiology of the wheat plants by reducing both $A$ and $g_{s}$, a fact additionally corroborated by the negative correlations between the blast severity and these two parameters. In any case, in agreement with the working hypothesis, the Si supply, by decreasing blast severity, could indirectly have helped to preserve, to some extent, the functionality of the photosynthetic apparatus and the gas exchange capacity upon fungal infection, as noted by the significantly higher values of $A, g_{s}$, and $E$ in the $+\mathrm{Si}$ plants compared with the -Si plants.

Despite many efforts to elucidate the mechanisms by which pathogens are capable of affecting plant photosynthetic capacity, these mechanisms remain elusive $(11,13)$. Debona et al. (13) demonstrated that the photosynthesis of wheat plants not supplied with Si was dramatically reduced during the infectious process of $P$. oryzae, due chiefly to the biochemical constraints linked to an apparently lower Rubisco activity. Here, it is proposed that the mechanism by which $P$. oryzae affected the photosynthetic performance clearly depended on the presence of $\mathrm{Si}$ (significant $\mathrm{Si}-$ plant inoculation interaction for $A$ and $g_{s}$ and for $C_{i}$ and $F_{v} / F_{m}$ ). Indeed, in the $+\mathrm{Si}$ plants, despite the early decreases in $A, g_{s}$, and $C_{i}$ at 48 hai, there were no major changes in these traits from 48 hai onward. In sharp contrast, the -Si plants displayed proportionally larger decreases in $A$ than in $g_{s}$ concomitantly with an unchanging $C_{i}$ at 120 hai; this result suggests that the anticipated lower influx of $\mathrm{CO}_{2}$ into the leaves caused by a decreased sto-

TABLE 2. Concentration of total chlorophyll $(\mathrm{Chl})$ and $\mathrm{Chl} a / b$ ratio in the leaves of wheat plants grown in a hydroponic culture containing $0 \mathrm{mM}(-\mathrm{Si})$ or $2 \mathrm{mM}(+\mathrm{Si})$ silicon $(\mathrm{Si})$ and noninoculated $(\mathrm{NI})$ or inoculated (I) with Pyricularia oryzae ${ }^{\mathrm{z}}$

\begin{tabular}{lccccc}
\hline & \multicolumn{2}{c}{ Total Chl $\left(\mathrm{mg} \mathrm{g}^{-1} \mathrm{FW}\right)$} & & \multicolumn{2}{c}{ Chl $a / b$ ratio } \\
\cline { 2 - 3 } \cline { 5 - 6 } Treatments & $\mathrm{NI}$ & $\mathrm{I}$ & & $\mathrm{NI}$ & $\mathrm{I}$ \\
\hline$-\mathrm{Si}$ & $7.87 \mathrm{Aa}$ & $1.98 \mathrm{Bb}$ & & $3.38 \mathrm{Aa}$ & $0.88 \mathrm{Bb}$ \\
$+\mathrm{Si}$ & $7.56 \mathrm{Aa}$ & $4.85 \mathrm{Ba}$ & & $3.24 \mathrm{Aa}$ & $2.67 \mathrm{Ba}$ \\
\hline
\end{tabular}

${ }^{\mathrm{z}}$ Means within each column followed by the same lowercase letter or means within a row followed by the same uppercase letter are not significantly different $(P=0.05)$ as determined by analysis of variance and Tukey's test; $n=5 ; \mathrm{FW}=$ fresh weight. matal aperture was not a primary factor associated with the reduction in $A$ in the $-\mathrm{Si}$ plants infected by $P$. oryzae. Therefore, decreases in $A$ during the infectious process of $P$. oryzae should be accounted for by nonstomatal factors. Although some diffusive limitations imposed by the mesophyll could not be excluded, the most likely explanation for the observed decreases in $A$ were associated with dysfunctions at the level of the biochemical reactions involving $\mathrm{CO}_{2}$ fixation, and this explanation is in agreement with the results obtained by Debona et al. (13).

In addition to likely compromising the biochemical ability for $\mathrm{CO}_{2}$ fixation, the infection by $P$. oryzae provoked a range of dysfunctions at the photochemical level, particularly at the later stages of fungal infection in the $-\mathrm{Si}$ plants. These dysfunctions could largely be avoided in the presence of $\mathrm{Si}$, which might directly be associated with lower blast symptoms in +Si plants, as highlighted above. Compared with the $+\mathrm{Si}$ plants, the maximum photochemical efficiency of photosystem II (analyzed as $F_{v} / F_{m}$ ) decreased to $<0.80$ for the - Si plants, which suggested the occurrence of chronic photoinhibition to photosynthesis (21). Concomitant decreases in the efficiency of the excitation energy captured by the open PSII reaction centers (estimated as $F_{v}{ }^{\prime} / F_{m}{ }^{\prime}$ ) and in the fraction of absorbed light that is dissipated photochemically (estimated as $q_{P}$ ) were also observed, which suggested that the infected plants were likely unable to fully capture and exploit the absorbed energy. Similar photochemical dysfunctions have been reported for other pathosystems such as that of Eucalyptus-Puccinia psidii (1). The decreases in $q_{P}$ can also be interpreted as an increased proportion of oxidized quinone A and, thus, represent a fraction of the PSII centers that are prone to suffer photoinhibitory damage (24). These results were accompanied by much lower decreases in ETR than in A, which potentially created an excess of reducing power that can trigger a range of photoinhibitory and photooxidative effects $(3,28)$. In the present study, the infected plants cope with such an excess by the reducing power via heat dissipation, as evidenced by the increased NPQ $(21,25)$. Nevertheless, heat dissipation was demonstrated as not sufficient to prevent photoinhibition, given the observed decreases in $F_{v} / F_{m}$. Additionally, these photochemical impairments are unlikely to directly constrain $A$, because $A$ decreased much more than ETR. However, these impairments contributed to blast progress, which is consistent with the stronger decreases in the total Chl pools that occurred in parallel with the preferential loss of Chl $a$ (that resulted in a lower $\mathrm{Chl} a / b$ ratio) in

TABLE 4. Leaf area (LA) and leaf dry mass (LDM) of wheat plants grown in a hydroponic culture containing $0 \mathrm{mM}(-\mathrm{Si})$ or $2 \mathrm{mM}(+\mathrm{Si})$ silicon $(\mathrm{Si})$ and noninoculated (NI) or inoculated (I) with Pyricularia oryzae ${ }^{\mathrm{z}}$

\begin{tabular}{lcc}
\hline Treatments & LA $\left(\mathrm{cm}^{2}\right.$ plant $\left.^{-1}\right)$ & LDM $\left(\mathrm{g} \mathrm{plant}^{-1}\right)$ \\
\hline$-\mathrm{Si}$ & 384.50 & 1.80 \\
$+\mathrm{Si}$ & 531.10 & 2.30 \\
$F$ test & $55.65^{*}$ & $21.95^{*}$ \\
$\mathrm{NI}$ & 497.1 & 2.12 \\
$\mathrm{I}$ & 383.1 & 1.71 \\
$F$ test & $5.83^{*}$ & $9.06^{*}$ \\
CV $(\%)$ & 19.90 & 18.00 \\
\hline
\end{tabular}

z Asterisk $(*)=$ significant at $P \leq 0.05 ; \mathrm{CV}=$ coefficient of variation; $n=5$.

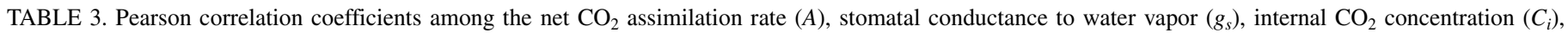
transpiration rate $(E)$, and the blast severity $(\mathrm{Sev})$ on the leaves of wheat plants grown in a hydroponic culture containing $0 \mathrm{mM}(-\mathrm{Si})$ or $2 \mathrm{mM}(+\mathrm{Si})$ silicon $(\mathrm{Si})^{\mathrm{z}}$

\begin{tabular}{|c|c|c|c|c|c|}
\hline Variables & $A$ & $g_{s}$ & $C_{i}$ & $E$ & $\mathrm{Sev}$ \\
\hline$A$ & $\cdots$ & $0.810 *$ & $-0.367 *$ & $0.528 *$ & $-0.770^{*}$ \\
\hline$g_{s}$ & $0.866^{*}$ & $\ldots$ & $0.035 \mathrm{~ns}$ & $0.752 *$ & $-0.613^{*}$ \\
\hline$C_{i}$ & $-0.373 *$ & $-0.036 \mathrm{~ns}$ & $\ldots$ & $0.165 \mathrm{~ns}$ & $0.534 *$ \\
\hline$E$ & $0.608 *$ & $0.761^{*}$ & $0.010 \mathrm{~ns}$ & $\ldots$ & $0.432 *$ \\
\hline $\mathrm{Sev}$ & $-0.780^{*}$ & $-0.667 *$ & $0.611^{*}$ & $-0.531 *$ & $\ldots$ \\
\hline
\end{tabular}

z Values below and above the diagonal correspond to the $-\mathrm{Si}$ and + Si treatments, respectively; $*=$ significant at $P \leq 0.01$ by $t$ test and ns $=$ not significant. 
the $-\mathrm{Si}$ plants compared with the $+\mathrm{Si}$ plants at 120 hai. In fact, under photooxidative conditions, Chl $a$ is more prone to photobleaching than Chl $b$ (29). Regardless, it must be emphasized that the wheat plants were grown under relatively low photon irradiances; had they been grown under field conditions where the irradiances can reach values as high as 2,000 $\mu \mathrm{mol}$ photons $\mathrm{m}^{-2} \mathrm{~s}^{-1}$ or even higher, the photoinhibitory damages caused by blast would be expected to be greatly exacerbated.

In conclusion, the results of this study clearly demonstrated that $\mathrm{Si}$ supplied to wheat plants resulted in lower blast symptoms. Even not having a direct metabolic role in photosynthesis upon infection, the protection against blast afforded by $\mathrm{Si}$ could be translated into improved gas exchange performance and less dysfunction at the photochemical level in $+\mathrm{Si}$ plants challenged with $P$. oryzae. These ameliorative effects of Si combined with the use of wheat cultivars with basal level of resistance to blast $(8,13)$ may be translated into useful tools to enhance wheat yield under conditions for the occurrence of severe blast epidemics.

\section{ACKNOWLEDGMENTS}

This study was supported by grants from National Council for Technological and Scientific Development $(\mathrm{CNPq})$ and the Fundação de Amparo a Pesquisa do Estado de Minas Gerais. F. A. Rodrigues and F. M. DaMatta thank the CNPq for their fellowships. C. E. Aucique Perez was supported by CAPES. We thank M. B. B. Cardona and P. E. M. Silva for their technical assistance.

\section{LITERATURE CITED}

1. Alves, A. A., Guimaraes, L. M., Chaves, A. R., DaMatta, F. M., and Alfenas, A. C. 2011. Leaf gas exchange and chlorophyll $a$ fluorescence of Eucalyptus urophylla in response to Puccinia psidii infection. Acta Physiol. Plant 33:1831-1839.

2. Ayres, P. G. 1980. Responses of stomata to pathogenic microorganisms. Pages 205-221 in: Stomatal Physiology vol. 8. P. G. Jarvis and T. A. Mansfield, eds. S.E.B. Sem., Cambridge University Press, Cambridge.

3. Baker, N. R. 2008. Chlorophyll fluorescence: a probe of photosynthesis in vivo. Annu. Rev. Plant Biol. 59:89-113.

4. Berger, S., Sinha, A. K., and Roitsch, T. 2007. Plant physiology meets phytopathology: plant primary metabolism and plant-pathogen interactions. J. Exp. Bot. 58:4019-4026.

5. Brunings, A. M., Datnoff, L. E., Ma, J. F., Mitani, N., Nagamura, Y., Rathinasabapathi, B., and Kirst, K. 2009. Differential gene expression of rice in responses to silicon and the rice blast fungus Magnaporthe oryzae. Ann. Appl. Biol. 155:161-170.

6. Campbell, C. L., and Madden, L. V. 1990. Introduction to Plant Disease Epidemiology. Wiley-Interscience, John Wiley \& Sons, New York.

7. Clark, R. B. 1975. Characterization of phosphates in intact maize roots. J. Agric. Food Chem. 23:458-460.

8. Cruz, C. D., Bockus, W. W., Stack, J. P., Tang, X., and Valent, B. 2012. Preliminary assessment of resistance among U.S. wheat cultivars to the Triticum pathotype of Magnaporthe oryzae. Plant Dis. 96:1501-1505.

9. Cruz, M. F. A., Prestes, A. R., Maciel, J. L., and Scheeren, P. 2010. Resistência parcial à brusone de genótipos de trigo comum e sintético nos estádios de planta jovem e de planta adulta. Trop. Plant Pathol. 25:24-25.

10. Dallagnol, L. J., Rodrigues, F. A., Chaves, A. R. M., Vale, F. X. R., and DaMatta, F. M. 2013. Photosynthesis and sugar concentration are impaired by the defective active silicon uptake in rice plants infected with Bipolaris oryzae. Plant Pathol. 62:120-129.

11. Dallagnol, L. J., Rodrigues, F. A., Martins, S. C. V., Calvette, P. C., and DaMatta, F. M. 2011. Alterations on rice leaf physiology during infection by Bipolaris oryzae. Australas. Plant Pathol. 40:360-365.

12. Datnoff, L. E., Rodrigues, F. A., and Seebold, K. W. 2007. Silicon and plant disease. Pages 233-246 in: Mineral Nutrition and Plant Disease. L. E. Datnoff, W. H. Elmer, and D. M. Huber, eds. The American Phytopathological Society, St. Paul, MN.

13. Debona, D., Rodrigues, F. A., Rios, J. A., and Telles, K. J. N. 2012. Biochemical changes in the leaves of wheat plants infected by Pyricularia oryzae. Phytopathology 102:1121-1129.

14. Detmann, K. C., Araújo, W. L., Martins, S. C. V., Sanglard, L. M. V. P., Reis, J. V., Detmann, E., Rodrigues, F. A., Nunes-Nesi, A., Fernie, A. R., and DaMatta, F. M. 2012. Silicon nutrition increases grain yield, which, in turn, exerts a feed-forward stimulation of photosynthetic rates via enhanced mesophyll conductance and alters primary metabolism in rice.
New Phytol. 196:752-762.

15. Epstein, E. 2009. Silicon: Its manifold roles in plants. Ann. Appl. Biol. 155:155-160.

16. Goulart, A. C. P., Sousa, P. G., and Urashima, A. S. 2007. Danos em trigo causados pela infecção de Pyricularia grisea. Summa Phytopathol. 33:358-363.

17. Igarashi, S., Utiamada, C. M., Igarashi, I. C., Kazuma, A. H., and Lopes, R. S. 1986. Pyricularia em trigo. 1. Ocorrência de Pyricularia sp. no estado do Paraná. Fitopatol. Bras. 11:351-352.

18. Keeping, M. G., and Reynolds, O. L. 2009. Silicon in agriculture: new insights, new significance and growing application. Ann. Appl. Biol. 155:153-154.

19. Kim, S. G., Kim, K. W., Park, E. W., and Choi, D. 2002. Silicon-induced cell wall fortification of rice leaves: A possible cellular mechanism of enhanced host resistance to blast. Phytopathology 92:1095-1103.

20. Korndörfer, G. H., Pereira, H. S., and Nolla, A. 2004. Análise de Silício: Solo, Planta e Fertilizante. Uberlândia, MG, Grupo de Pesquisa em Silício, ICIAG-Universidade Federal de Uberlândia (Boletim Técnico 1). Uberlandia, Minas Gerais State, Brazil.

21. Krause, G. H., and Weis, E. 1991. Chlorophyll fluorescence and photosynthesis: The basics. Annu. Rev. Plant Physiol. Plant Mol. Biol. 42:313349.

22. Lancashire, P. D., Bleiholder, H., Langelüddecke, P., Stauss, R., Van Den Boom, T., Weber, E., and Witzenberger, A. 1991. An uniform decimal code for growth stages of crops and weeds. Ann. Appl. Biol. 119:561-601.

23. Liang, Y., Sun, W., Zhu, Y. G., and Christie, P. 2006. Mechanisms of silicon-mediated alleviation of abiotic stresses in higher plants: A review. Environ. Pollut. 147:422-428.

24. Lima, A. L. S., DaMatta, F. M., Pinheiro, H. A., Totola, M. R., and Loureiro, M. E. 2002. Photochemical responses and oxidative stress in two clones of Coffea canephora under water deficit conditions. Environ. Exp. Bot. 47:239-247.

25. Logan, B. A., Adams, W. W., and Demming-Adams, B. 2007. Avoiding common pitfalls of chlorophylls fluorescence analysis under field conditions. Funct. Plant Biol. 34:853-859.

26. Ma, J. F., Tamai, K., Ichii, M., and Wu, G. F. 2002. A rice mutant defective in Si uptake. Plant Physiol. 130:2111-2117.

27. Matos, F. S., Wolfgramm, R., Gonçalves, F. V., Cavatte, P. C., Ventrella, M. C., and DaMatta, F. M. 2009. Phenotypic plasticity in response to light in the coffee tree. Environ. Exp. Bot. 67:421-427.

28. Maxwell, K., and Johnson, G. N. 2000. Chlorophyll fluorescence-a practical guide. J. Exp. Bot. 51:659-668.

29. Murchie, E. H., and Horton, P. 1997. Acclimation of photosynthesis to irradiance and spectral quality in British plant species: Chlorophyll content, photosynthetic capacity and habitat preference. Plant Cell Environ. 20:438-448.

30. Petit, A. N., Vaillant, N., Boulay, M., Clément, C., and Fontaine, F. 2006. Alteration of photosynthesis in grapevines affected by esca. Phytopathology 96:1060-1066.

31. Resende, R. S., Rodrigues, F. A., Cavatte, P. C., Martins, S. C. V., Moreira, W. R., Chaves, A. R. M., and DaMatta, F. M. 2012. Leaf gas exchange and oxidative stress in sorghum plants supplied with silicon and infected by Colletotrichum sublineolum. Phytopathology 102:892898.

32. Rios, J. A., Debona, D., Duarte, H. S. S., and Rodrigues, F. A. 2013. Development and validation of a standard area diagram set to assess blast severity on wheat leaves. Eur. J. Plant Pathol. Online publication. doi:10.1007/s10658-013-0191-x

33. Rodrigues, F. A., Benhamou, N., Datnoff, L. E., Jones, J. B., and Bélanger, R. R. 2003. Ultrastructural and cytochemical aspects of silicon mediated rice blast resistance. Phytopathology 93:535-546.

34. Rodrigues, F. A., Jurick, W. M., Datnoff, L. E., Jones, J. B., and Rollins, J. A. 2005. Silicon influences cytological and molecular events in compatible and incompatible rice-Magnaporthe grisea interactions. Physiol. Mol. Plant Pathol. 66:144-159.

35. Rodrigues, F. A., McNally, D. J., Datnoff, L. E., Jones, J. B., Labbé, C., and Benhamou, N. 2004. Silicon enhances the accumulation of diterpenoid phytoalexins in rice: A potential mechanism for blast resistance. Phytopathology 94:177-183.

36. Shtienberg, D. 1992. Effects of foliar diseases on gas exchange: A comparative study. Phytopathology 82:760-765.

37. Tamai, K., and Ma, J. F. 2008. Reexamination of silicon effects on rice growth and production under field conditions using a low silicon mutant. Plant Soil 307:21-27.

38. Xavier Filha, M. S., Rodrigues, F. A., Domiciano, G. P., Oliveira, H. V., Silveira, P. R., and Moreira, W. R. 2011. Wheat resistance to leaf blast mediated by silicon. Australas. Plant Pathol. 40:28-38.

39. Zhao, D., Glynn, N. C., Glaz, B., Comstock, J. C., and Sood, S. 2011. Orange rust effects on leaf photosynthesis and related characters of sugarcane. Plant Dis. 95:640-647. 